\title{
IASSIST gone glocal
}

Welcome to the special double issue of IASSIST Quarterly 2021 (IQ vol. 45(3-4) 2021).

IASSIST is an acronym. You may think that the word is the contraction of the two words 'I assist'. In my mind, you are right! Whether the word IASSIST or the long explanation of seven words came first is the problem of the chicken and the egg. However, it is undisputed that when it is spelled out, the first I in IASSIST is for International. That has been so from its founding in 1974. Having IASSIST members in USA, Canada, and some (west) European countries was for a long time what we myopic westerners considered to be international. It is with great pleasure that IASSIST Quarterly now presents a double issue from a regional workshop in Africa. Even in 2021, it is only a small number of IASSIST's members who are from regions not part of the western world. However, having a special issue from the African region is an important contribution to making IASSIST truly international. The phrase 'think globally, act locally' is a good framing of the compressed word 'glocal'.

This special issue was compiled by guest editors Winny Nekesa Akullo and Robert Stalone Buwule, and they were also behind the Africa Regional Workshop that took place at Makerere University (Kampala, Uganda) on January 11 to 13, 2021. Winny Nekesa Akullo works as Head, Library and Documentation Centre at Public Procurement and Disposal of Public Assets Authority in Uganda, and is the IASSIST Africa Regional Secretary. Robert Stalone Buwule is Senior Assistant Librarian at Kyambogo University, also in Uganda.

The themes of the workshop addressed a world issue: 'Data Literacy as a catalyst for achieving Sustainable Development Goals (SDGs)'. Thus, global problems were addressed from a local viewpoint. Great thanks to Winny and Robert for their lead in the arrangement of the workshop and extra thanks to them for collecting, editing, and making the papers of the regional workshop available to us all, and for making the regional international and the local global.

Enjoy the reading!

Submissions of papers for the IASSIST Quarterly are always very welcome. We welcome input from IASSIST conferences or other conferences and workshops, from local presentations or papers especially written for the $I Q$. When you are preparing such a presentation, give a thought to turning your one-time presentation into a lasting contribution. Doing that after the event also gives you the opportunity of improving your work after feedback. We encourage you to login or create an author profile at https://www.iassistquarterly.com (our Open Journal System application). We permit authors to have 'deep links' into the $I Q$ as well as deposition of the paper in your local repository. Chairing a conference session or workshop with the purpose of aggregating and integrating papers for a special issue $I Q$ is also much appreciated as the information reaches many more people than the limited number of session participants and will be readily available on the IASSIST Quarterly website at https://www.iassistquarterly.com. Authors are very welcome to take a look at the instructions and layout: https://www.iassistquarterly.com/index.php/iassist/about/submissions. Authors can also contact me directly via e-mail: kbr@sam.sdu.dk. Should you be interested in compiling a special issue for the IQ as guest editor(s) I will also be delighted to hear from you.

Karsten Boye Rasmussen - December 2021

1/1 Rasmussen, Karsten Boye (2021), Editor's notes: IASSIST is now glocal., IASSIST Quarterly 45(3-4), pp. 1-1. DOI https://doi.org/10.29173/iq1025 